\title{
Targeted Strategies for Henipavirus Therapeutics
}

\author{
Katharine N. Bossart ${ }^{*}$, John Bingham and Deborah Middleton
}

\author{
CSIRO Livestock Industries, Australian Animal Health Laboratory, Geelong, Victoria 3220, Australia
}

\begin{abstract}
Hendra and Nipah viruses are related emergent paramyxoviruses that infect and cause disease in animals and humans. Disease manifests as a generalized vasculitis affecting multiple organs, but is the most severe in the respiratory and central nervous systems. The high case fatality and person-to-person transmission associated with the most recent $\mathrm{NiV}$ outbreaks, and the recent re-emergence of $\mathrm{HeV}$, emphasize the importance and necessity of effective therapeutics for these novel agents. In recent years henipavirus research has revealed a more complete understanding of pathogenesis and, as a consequence, viable approaches towards vaccines and therapeutics have emerged. All strategies target early steps in viral replication including receptor binding and membrane fusion. Animal models have been developed, some of which may prove more valuable than others for evaluating the efficacy of therapeutic agents and regimes. Assessments of protective host immunity and drug pharmacokinetics will be crucial to the further advancement of therapeutic compounds.
\end{abstract}

\section{INTRODUCTION}

Hendra virus $(\mathrm{HeV})$ and Nipah virus $(\mathrm{NiV})$ are closely related highly pathogenic paramyxoviruses that have emerged independently in the past 15 years and continue to emerge in new locations. Flying foxes in the genus Pteropus are considered to be the natural reservoir for both viruses as demonstrated by seroconversion and isolation of $\mathrm{HeV}$ - and NiV-like viruses from bat tissues and secretions [1,2]. Additionally, extensive serological surveys have not demonstrated the presence of $\mathrm{HeV}$ - or $\mathrm{NiV}$-specific antibodies in other species. Indeed the flying fox geographic range encompasses all locations where $\mathrm{HeV}$ and $\mathrm{NiV}$ have been found. Paramyxoviruses are large, enveloped, negative-sense ssRNA viruses, and include such well-known members as measles virus (MeV), simian virus 5 (SV5), and respiratory syncytial virus (RSV) [3]. It is a diverse virus family, with various members causing common upper and lower respiratory tract infections to less common manifestations of neurological disease. In contrast, $\mathrm{NiV}$ and $\mathrm{HeV}$ are distinguished from all other paramyxoviruses most notably by their broad species tropism and high case fatality, and they have been classified into the new Henipavirus genus within the family Paramyxoviridae [4]. HeV has appeared sporadically in Australia since 1994 where infection has been transmitted from horses to humans (reviewed in [5]). Presumably horses become infected through spillover events from flying foxes, although no virus has been isolated from flying foxes during outbreaks. In horses, the disease presented as a severe respiratory infection, while one of the two reported human mortalities had severe respiratory disease, and the other succumbed to encephalitis 13 months following the presumed time of exposure. Recent outbreaks where horse fatalities were documented include 1999, 2004 and 2006 and although no human mortalities have occurred, one mildly ill, seroconverting, human case has been reported [6-8]. NiV first appeared in peninsular Malaysia and Singapore in 1998-9

*Address correspondence to this author at the Australian Animal Health Laboratory, CSIRO Livestock Industries, 5 Portarlington Road, Geelong, Victoria 3220, Australia; Tel: 61-3-5227-5125; Fax: 61-3-5227-5555; Email: Katharine.Bossart@csiro.au and the majority of infections occurred in pigs with subsequent transmission to humans (reviewed in $[9,10]$ ). In pigs, infection was largely subclinical; however, where clinical disease was observed, it manifested as respiratory and encephalitic disease with low fatality ratios for respiratory cases. In contrast, humans developed severe febrile encephalitis with high case fatality and up to $25 \%$ of $\mathrm{NiV}$ cases also exhibited respiratory signs including non-productive cough. Interestingly, both relapsing and late-onset encephalitis syndromes with significant fatality $(\sim 18 \%)$ have been recognized following either acute $\mathrm{NiV}$ encephalitic episodes or non-encephalitic/ asymptomatic infection. $\mathrm{NiV}$ has reemerged numerous times since 1998: twice in 2001 in Bangladesh and West Bengal India, again in 2003 in Bangladesh, three times in Bangladesh in 2004 and 2005, and most recently in 2007 in Nadia, India [11-15]. Significant observations in all of the Bangladesh and Indian NiV outbreaks have included a higher incidence of acute respiratory distress syndrome in conjunction with encephalitis, epidemiological findings consistent with person-to-person transmission [16], and higher case fatality ratios $(\sim 75 \%)$. Furthermore, no intermediate or amplification host has been identified and direct transmission of NiV from the reservoir host to humans has been suggested. In West Bengal in 2001 there was no concurrent illness in animals and in Bangladesh in 2004 the common epidemiological link among cases was drinking fresh date palm sap [12, 17]. In general, it is believed that date palm sap is regularly contaminated by flying foxes and their excretions.

$\mathrm{NiV}$ and $\mathrm{HeV}$ are classified as zoonotic biosafety level 4 (BSL-4) viruses and infectious virus can only be studied at a handful of laboratories worldwide. Both viruses have also been included among the various pathogenic agents of biodefense concern and each are classified as priority pathogens in category $\mathrm{C}$ by the Centers for Disease Control and Prevention (CDC) and the National Institute of Allergy and Infectious Diseases (NIAID). The category $\mathrm{C}$ agents include high emerging pathogens with the potential for causing morbidity and mortality with major economic and health impacts. Henipaviruses in particular, could be engineered for mass dissemination because of their availability from natural sources and their relative ease of propagation and dissemina- 
tion. Currently there are no specific antiviral therapies or vaccines available for treating or preventing $\mathrm{NiV}$ or $\mathrm{HeV}$ infection resulting from a natural outbreak, laboratory accident or deliberate misuse.

\section{PATHOGENESIS IN HUMANS}

There have been two fatal cases of $\mathrm{HeV}$ infection in humans, the first presented with severe respiratory disease and upon autopsy the patient's lungs had gross lesions of congestion, hemorrhage and edema associated with chronic alveolitis and syncytial cell formation. The second fatal case presented thirteen months post-exposure and exhibited leptomeningitis with lymphocytes and plasma cells and foci of necrosis in various parts of the brain parenchyma (reviewed in [18]). Multinucleate endothelial cells were also present in the viscera as well as in the brain. During the first NiV outbreak in Malaysia encephalitis killed 105 of 265 infected individuals [19]. Immuno- and histological features were described as a systemic endothelial infection accompanied by vasculitis, thrombosis, ischaemia and necrosis [20]. These changes were especially noted in the central nervous system (CNS). Immunohistochemical analyses demonstrated the widespread presence of $\mathrm{NiV}$ antigens both in neurons and other parenchymal cells in necrotic foci in the CNS and in endothelial cells of affected blood vessels. Evidence of vasculitis and endothelial infection was also seen in most organs examined. Disseminated endothelial cell infection, vasculitis, thrombosis and CNS parenchymal cell infection all appear to play essential roles in the fatal outcome of human NiV infection $[18,20]$. In the more recent NiV outbreaks in India and Bangladesh, similar clinical signs were noted. However, a higher incidence of acute respiratory distress syndrome in conjunction with encephalitis was also described $[11,12]$.

\section{VIRUS ENTRY INTO HOST CELLS}

Paramyxoviruses contain two major membrane-anchored envelope glycoproteins that are required for infection of a receptive host cell. All members contain an attachment glycoprotein, which binds the host cell receptor, while the second is the fusion $(\mathrm{F})$ glycoprotein, which mediates $\mathrm{pH}$ independent membrane fusion between the virus and its host cell (reviewed in [3]). Following virus attachment to a permissive host cell, paramyxovirus mediated membrane fusion occurs at neutral $\mathrm{pH}$ resulting in delivery of the nucleocapsid into the cytoplasm of the host cell. Most paramyxovirus attachment glycoproteins possess hemagglutinin and neuraminidase activities (HN), which bind sialic acid moieties. Virion attachment most likely occurs through binding of multiple sialic acid-expressing proteins on the cell surface. The morbillivirus attachment glycoproteins $(\mathrm{H})$ contain only hemagglutinin activity and do not bind sialic acid. Three morbilliviruses, measles virus, canine distemper virus and rinderpest virus, can employ cell-surface proteins as viral receptors [21-26]. $\mathrm{HeV}$ and $\mathrm{NiV}$ possess attachment glycoproteins $(\mathrm{G})$ that lack hemagglutinin and neuraminidase activities and are the only other paramyxoviruses known to utilize host cell proteins that do not contain sialic acid as viral receptors. Specifically, ephrin-B2 ligand was identified as a receptor utilized by $\mathrm{HeV}$ and $\mathrm{NiV}$ for infection [27, 28] and subsequently, ephrin-B3 ligand was identified as an alternate receptor for $\mathrm{NiV}$ [29]. Ephrin molecules are members of a family of receptor tyrosine kinase ligands and are highly conserved across vertebrate species [30, 31]. Ephrin ligands and their receptors play important roles in regulation of tissue assembly and cell migration [30] and are critical to brain function, neuronal networking and morphogenesis [32]. Ephrin-B2 ligand is an artery-specific protein that mediates blood vessel development and maturation [33, 34]. Neurons smooth muscle, arterial endothelial cells and capillaries all exhibit high levels of ephrin-B2 ligand expression consistent with the known tissue tropism of $\mathrm{HeV}$ and $\mathrm{NiV}$ in vivo. Ephrin-B3 ligand is expressed in certain neural subsets and may play an important role in $\mathrm{HeV}$ and $\mathrm{NiV}$ infection in the CNS. All paramyxoviruses $\mathrm{F}$ glycoproteins, including $\mathrm{HeV}$ and $\mathrm{NiV}$, are typical class I fusion proteins that utilize two internal heptad repeats to mediate membrane merger (reviewed in [35]). Because both attachment and fusion are critical steps for productive infection, molecules that interfere with either process represent potential antiviral agents and in fact the most extensively characterized novel therapeutics fall within this category as will be discussed below.

\section{ANIMAL MODELS}

$\mathrm{HeV}$ and $\mathrm{NiV}$ are currently classified as BSL-4 agents and consequently human efficacy studies for testing potential therapeutic products are not easily achievable. In 2002, the U.S. Food and Drug Administration (FDA) implemented the Animal Efficacy Rule for the development of therapeutic products under these circumstances. Specifically, FDA can rely on evidence derived from animal studies in the evaluation of product effectiveness when particular criteria are met, such as a well-understood mechanism for both the pathogenicity of the agent and the underlying mode of action of the product. Importantly, the therapeutic effect must also be demonstrated in more than one animal species. Once these criteria have been met, human clinical trials could commence, most likely in populations at high risk of natural infection by $\mathrm{HeV}$ and $\mathrm{NiV}$.

A strong epidemiological association existed in Malaysia between human $\mathrm{NiV}$ infection and close direct contact with pigs, especially sick and dying animals. No direct association with flying foxes was made. An epidemiological link has been noted between $\mathrm{HeV}$ infection in people and horses dying from $\mathrm{HeV}$ disease. Again, neither $\mathrm{HeV}$ disease nor seroconversion has ever been identified in wildlife carers who came into close and regular contact with sick and injured bats. While both horses and pigs have been experimentally infected with $\mathrm{HeV}$ and $\mathrm{NiV}$, respectively [42, 44], neither represents a practical option for multiple experimental efficacy studies. Large animals such as horses are difficult to manage in sufficient numbers under BSL-4 conditions and in pigs NiV infection is mostly inconsequential from a clinical perspective. For the purposes of this review we will focus on the smaller animal model systems that have been explored (Table 1). There was no serological evidence of NiV infection in rodents in Malaysia [9, 45]. However, attempts were made to infect mice experimentally. $\mathrm{NiV}$ and $\mathrm{HeV}$ do not cause disease in mice after subcutaneous administration $\left(5,000\right.$ TCID $\left._{50} \mathrm{HeV}\right)$ (Crameri, G and Eaton, B.T., unpublished observations) or with either an intranasal $\left(6 \times 10^{5} \mathrm{pfu}\right.$ $\mathrm{NiV})$ or intraperitoneal $\left(10^{7} \mathrm{pfu} \mathrm{NiV}\right)$ challenge of $\mathrm{NiV}$ [40], although the $\mathrm{HeV}$ is lethal if administered intracranially. Rabbits are not susceptible to $\mathrm{HeV}$ associated disease when 
Table 1. Small Animal Models for Henipavirus Infection

\begin{tabular}{|c|c|c|c|c|c|c|c|}
\hline & \multicolumn{3}{|c|}{ Challenge Dose } & \multicolumn{3}{|c|}{ Pathology } & \multirow[b]{2}{*}{ Ref. } \\
\hline & $\begin{array}{l}\text { Intra- } \\
\text { Peritoneal }\end{array}$ & Subcutaneous & $\begin{array}{c}\text { Intranasal-Oral- } \\
\text { Oronasal }\end{array}$ & General & Lung & Brain & \\
\hline $\begin{array}{c}\text { Guinea } \\
\text { pig } \\
\mathbf{H e V}\end{array}$ & & $\begin{array}{l}5,000 \mathrm{TCID}_{50} \\
50,000 \mathrm{TCID}_{50}\end{array}$ & & $\begin{array}{l}\text { Weakness, lethargy, } \\
\text { abortion, head tilt. Death } \\
\text { or euthanasia 6-15 days } \\
\text { PI. Vascular degenera- } \\
\text { tion in multiple organs. } \\
\text { Immuno-staining of } \\
\text { blood vessels. }\end{array}$ & $\begin{array}{l}\text { Fibrinoid degenera- } \\
\text { tion of blood ves- } \\
\text { sels, syncytia of } \\
\text { endothelium and } \\
\text { alveolar walls }\end{array}$ & $\begin{array}{l}\text { microscopical } \\
\text { lesions of } \\
\text { encephalitis in } \\
8 / 15 \text { guinea- } \\
\text { pigs subcuta- } \\
\text { neously inocu- } \\
\text { lated with } \\
30,000-50,000 \\
\text { TCID }_{50}\end{array}$ & [36-38] \\
\hline $\begin{array}{c}\text { Guinea } \\
\text { pig } \\
\text { NiV }\end{array}$ & $50,000 \mathrm{TCID}_{50}$ & & & $\begin{array}{c}\text { Mild behavioral } \\
\text { changes, ataxia. Eutha- } \\
\text { nasia } 7-10 \text { DPI. Infec- } \\
\text { tion in } 3 / 8 \text { animals. } \\
\text { Vasculitis, fibrinoid } \\
\text { necrosis of vessels in } \\
\text { multiple organs, } \\
\text { oophoritis, endometrial } \\
\text { necrosis. Antigen in } \\
\text { endothelium, syncytia, } \\
\text { blood vessel walls, } \\
\text { myometrium and endo- } \\
\text { metrium. }\end{array}$ & $\begin{array}{l}\text { Lung lesions not } \\
\text { observed }\end{array}$ & $\begin{array}{l}\text { Encephalitis } \\
\text { not observed }\end{array}$ & [39] \\
\hline $\begin{array}{c}\text { Golden } \\
\text { Hamster } \\
\text { NiV }\end{array}$ & $\begin{array}{c}100-10,000 \\
\text { pfu }\end{array}$ & & $\begin{array}{c}1000-1,000,000 \\
\text { pfu }\end{array}$ & $\begin{array}{l}\text { Tremors, paralysis, } \\
\text { lethargy, breathing } \\
\text { difficulty. Death } 9-29 \\
\text { DPI. Vascular fibrinoid } \\
\text { necrosis and inflamma- } \\
\text { tion in multiple organs. } \\
\text { Antigen and genome in } \\
\text { endothelial cells, syn- } \\
\text { cytia and tunica media } \\
\text { of blood vessels. }\end{array}$ & $\begin{array}{l}\text { Paranchymal in- } \\
\text { flammation, vascu- } \\
\text { litis } \\
* *\end{array}$ & $\begin{array}{c}\text { Vasculitis. } \\
\text { Mild inflam- } \\
\text { mation of } \\
\text { parenchyma } \\
\text { and meninges. } \\
\text { Antigen, ge- } \\
\text { nome and } \\
\text { inclusion bod- } \\
\text { ies in neurons } \\
* *\end{array}$ & [40] \\
\hline $\begin{array}{l}\text { Cat } \\
\mathrm{HeV}\end{array}$ & & $5,000 \mathrm{TCID}_{50}$ & $50,000 \mathrm{TCID}_{50}$ & $\begin{array}{l}\text { Death or euthanasia 6-7 } \\
\text { DPI. Vascular lesions } \\
\text { and paranchymal degen- } \\
\text { eration in gastrointesti- } \\
\text { nal tract and lymphoid } \\
\text { organs. }\end{array}$ & $\begin{array}{l}\text { Interstitial pneu- } \\
\text { monia, vascular } \\
\text { necrosis, endothe- } \\
\text { lial syncytia. } \\
\text { ** }\end{array}$ & $\begin{array}{l}\text { Encephalitis } \\
\text { not reported }\end{array}$ & {$[36,41]$} \\
\hline $\begin{array}{l}\text { Cat } \\
\text { NiV }\end{array}$ & & $500 \mathrm{TCID}_{50}$ & $50,000 \mathrm{TCID}_{50}$ & $\begin{array}{l}\text { Euthanasia 7-9 DPI after } \\
\text { short febrile illness and } \\
\text { increase in respiratory } \\
\text { rate; clinical resolution } \\
\text { in one cat. Necrosis in } \\
\text { spleen, inflammation of } \\
\text { bladder, necrotizing } \\
\text { lymphadenitis. }\end{array}$ & $\begin{array}{l}\text { Focal necrotizing } \\
\text { alveolitis with } \\
\text { syncytia, bronchio- } \\
\text { litis, fibrinoid ne- } \\
\text { crosis of blood } \\
\text { vessel walls, endo- } \\
\text { thelial syncytia. } \\
\text { Antigen in affected } \\
\text { bronchial and al- } \\
\text { veolar epithelium, } \\
\text { syncytia and blood } \\
\text { vessels. } \\
* *\end{array}$ & $\begin{array}{l}\text { Meningitis, } \\
\text { meningeal } \\
\text { vasculitis with } \\
\text { endothelial } \\
\text { syncytia; dis- } \\
\text { tinct encephali- } \\
\text { tis has not been } \\
\text { identified }\end{array}$ & {$[42,43]$} \\
\hline $\begin{array}{l}\text { Ferret } \\
\mathrm{NiV}^{*}\end{array}$ & & & $500-50,000 \mathrm{TCID}_{50}$ & $\begin{array}{c}\text { Fever, depression and } \\
\text { weakness. Euthanasia } 6 \\
\text { - } 10 \text { DPI following } 1-2 \\
\text { days fever. Vascular } \\
\text { fibrinoid necrosis in } \\
\text { multiple organs, necro- } \\
\text { tising alveolitis, syncytia } \\
\text { of endothelium and } \\
\text { alveolar epithelium, } \\
\text { necrotizing lymphadeni- } \\
\text { tis. Antigen in blood } \\
\text { vessel walls and syn- } \\
\text { cytia. }\end{array}$ & $\begin{array}{l}\text { Vascular fibrinoid } \\
\text { necrosis, necrotis- } \\
\text { ing alveolitis, syn- } \\
\text { cytia of alveolar } \\
\text { epithelium. Anti- } \\
\text { gen in blood vessel } \\
\text { walls and syncytia. } \\
\text { ** }\end{array}$ & $\begin{array}{l}\text { Not yet deter- } \\
\text { mined }\end{array}$ & $\begin{array}{l}\text { Unpub- } \\
\text { lished } \\
\text { (Bos- } \\
\text { sart, K, } \\
\text { Bing- } \\
\text { ham, J, } \\
\text { and } \\
\text { Middle- } \\
\text { ton, D) }\end{array}$ \\
\hline
\end{tabular}


challenged subcutaneously $\left(5,000 \quad \mathrm{TCID}_{50} \mathrm{HeV}\right)$ [46]. Guinea pigs were experimentally infected with $\mathrm{HeV}$ soon after its discovery $\left(5,000-50,000 \mathrm{TCID}_{50} \mathrm{HeV}\right)$ [46] and developed generalized vasculitis affecting lung, kidney, spleen, lymph nodes, gastrointestinal tract, and skeletal and intercostal muscles [36, 38]. However, in spite of vascular involvement of the lung, there was little or no pulmonary edema. $\mathrm{NiV}$ infection in the guinea pig $\left(50,000 \mathrm{TCID}_{50} \mathrm{NiV}\right)$ clinically manifested as ruffled fur and abnormal (less fearful) behavior [39] with gross pathology limited to edema of the mesentery, broad ligament, and retroperitoneal tissues. Significant microscopic pathology included vasculitis with fibrinoid necrosis and endothelial syncytial cell formation in the myocardium, kidney, lymph node, spleen, myometrium, retroperitoneal tissues, and submucosal vessels of the bladder. Oophoritis and the presence of hemorrhagic corpora lutea were also noted together with endometrial degeneration and necrosis accompanied by multinucleated cells.

A golden hamster animal model for acute NiV virus infection has been established where, importantly, encephalitis and neuron infection were demonstrated similar to those seen in NiV-infected humans [40]. The $\mathrm{LD}_{50}$ values for hamsters inoculated by intraperitoneal and intranasal routes were 270 pfu and 47,000 pfu, respectively. Notably, the brain was the most severely affected organ in terms of vascular and parenchymal lesions. Neurons in the vicinity of vascultis showed numerous cytoplasmic eosinophilic inclusion bodies and both viral antigen and RNA were found extensively throughout neurons. Ultrastructural analysis revealed cytoplasmic inclusions composed of defined herringbone nucleocapsids typical of paramyxoviruses. However, although $\mathrm{HeV}$ and $\mathrm{NiV}$ clearly cause systemic disease in humans, $\mathrm{NiV}$ was not detected in serum samples from infected hamsters. Moreover, the pathology seen in the lungs and kidneys of NiVinfected hamsters differed from that seen in $\mathrm{HeV}$-infected horses and $\mathrm{NiV}$-infected humans. $\mathrm{HeV}$ infection of hamsters has not been reported.

Experimental $\mathrm{HeV}$ infection of cats has been performed and findings from those studies were similar to those of horses and humans, namely generalized vascular disease with the most severe effects seen in the lung $[36,44]$. NiV infection in cats was comparable to that observed with $\mathrm{HeV}$ except that with $\mathrm{NiV}$ there was also extensive inflammation of the upper and lower respiratory tract epithelium, associated with the presence of viral antigen [42], similar to the severe respiratory disease observed in humans in the recent $\mathrm{NiV}$ outbreaks in Bangladesh. Cats succumb to infection 6 to 10 days following parenteral inoculation of as low as 500 $\mathrm{TCID}_{50} \mathrm{NiV}$ [43], or oronasal administration of 50,000, $\mathrm{TCID}_{50}$ of low passage, plaque purified $\mathrm{HeV}[41,42,46]$ or $\mathrm{NiV}$ (Bossart, K., Bingham, J. and Middleton, D., unpublished data). Gross pathology common to both $\mathrm{HeV}$ and $\mathrm{NiV}$ infection of cats consisted of hydrothorax, dense purple-red consolidation in the lung with fluid accumulation and froth in the bronchi (reviewed in [18]. Histologically cats infected with $\mathrm{NiV}$ develop a necrotizing alveolitis, with necrotic foci developing within a range of other organs, particularly kidney, spleen, lymph nodes, bladder, ovaries, adrenal and meninges. Studies on cats that were euthanized early in the course of the infection (1 day after the onset of fever, as determined by radiotelemetry measurement of body temperature) indicated that alveolar infection by $\mathrm{NiV}$ preceded vas- cular infection suggesting an increased tropism for alveolar epithelium as compared to vascular tissue (Bingham, J., unpublished observation). Thus evidence to date indicates that the cat represents an animal model in which henipavirus induced pathology closely resembles the lethal respiratory disease caused by $\mathrm{HeV}$ and $\mathrm{NiV}$ in humans.

Experimental NiV infection in Pteropid bats has been attempted [39]. All bats that were challenged with 50,000 $\mathrm{TCID}_{50} \mathrm{NiV}$ remained clinically well throughout the study period and no febrile responses were recorded following $\mathrm{NiV}$ inoculation via a parenteral route. Challenged bats developed a sub-clinical infection characterized by episodic viral shedding in urine, limited presence of virus within selected viscera and seroconversion. No gross abnormalities were identified on post-mortem examination of animals at various times post exposure; all bat tissues were negative upon immunohistochemical labeling for $\mathrm{NiV}$ antigen.

Recently, we have been evaluating the potential of the ferret as an improved animal model for NiV infection. Ferrets have emerged as important animal models for several major respiratory diseases including highly pathogenic avian influenza [47], severe acute respiratory syndrome (SARS) [48], and also morbilliviruses [49], the closest relatives to $\mathrm{HeV}$ and NiV. Significant similarity exists between ferret and human lung physiology and morphology [50] and ferrets have been used previously for toxicology and biological safety assessment studies [51]. We have confirmed that ferrets are susceptible to $\mathrm{NiV}$ infection with disease developing 6 to 10 days following oronasal administration of 500 to 50,000 TCID 50 (Bossart, K., Bingham, J. and Middleton, D., unpublished data). A lower dose of $50 \mathrm{TCID}_{50}$ failed to produce infection as defined by fever, illness, detection of virus, viral antigen or viral genome, histopathological lesions or seroconversion. Infection first manifested as fever and this was followed by inappetance and severe depression. A mild increase in respiratory rate in some animals was attributable to fever with one ferret showing tremors and hindlimb weakness. Gross pathology included subcutaneous edema of the head, hemorrhagic lymphadenopathy of submandibular, retropharyngeal and sometimes visceral lymph nodes, numerous diffuse pin-point hemorrhagic nodules scattered throughout the pulmonary parenchyma and petechial hemorrhages of the renal cortex. Histopathological lesions included focal necrotizing alveolitis, vasculitis, degeneration of glomerular tufts, and focal necrosis in a range of other tissues, including lymph nodes, spleen, adrenal cortex, bladder and ovary. Lesions in each case were associated with significant quantities of viral antigen, as determined by immunohistochemical staining (Fig. 1). Syncytial cells were also frequently present in lesions. NiV genome was detected in blood, brain, liver, testes, adrenal, kidney, lung, lymph node and spleen. These preliminary results are encouraging and indicate that the ferret may be another suitable model for human infection.

The golden hamster, cat and ferret are practical laboratory animal models that can be used to evaluate aspects of disease caused by either $\mathrm{HeV}$ or $\mathrm{NiV}$, and each is more amenable to therapeutic efficacy testing than large domestic animals particularly for these BSL-4 pathogens. In hamsters $\mathrm{NiV}$-associated encephalitis was unique among the small animal models; however, it is unclear if this was due to the 

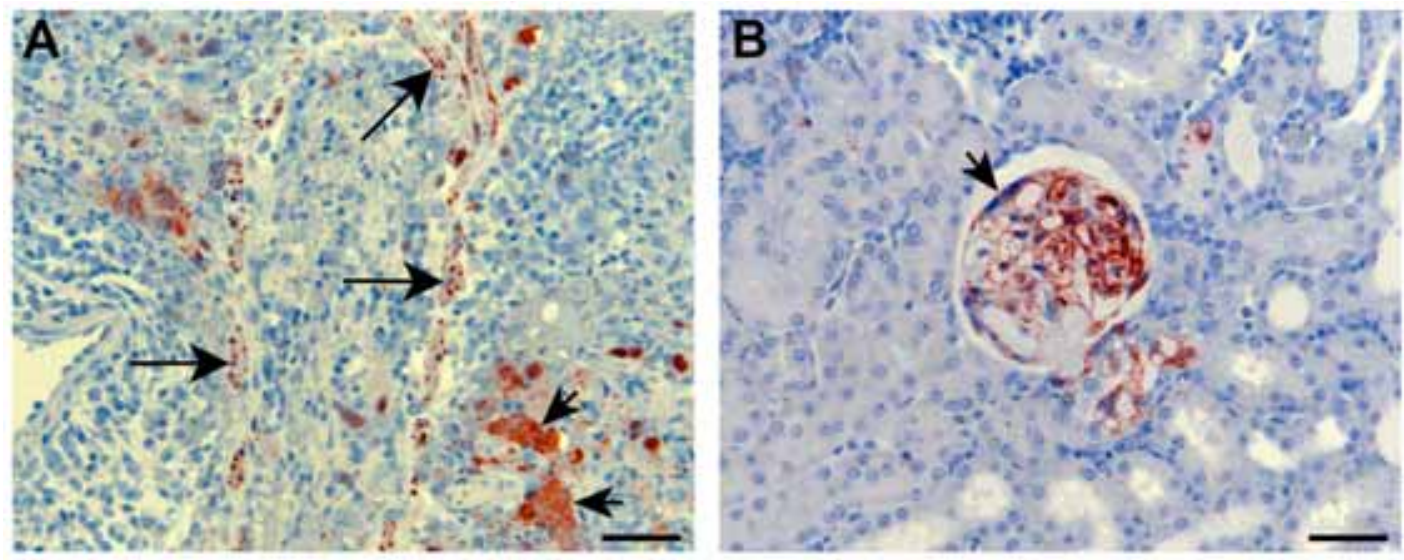

Fig. (1). Histopathology and immunohistochemistry associated with NiV infection in ferrets. A: Severe necrotizing alveolitis and vasculitis with positive staining for $\mathrm{NiV}$ nucleoprotein antigen in blood vessel wall (long arrows) and syncytial cells (short arrows). B: Acute glomerular degeneration with associated NiV nucleoprotein antigen in ferret kidney. A syncytial cell (arrow) is visible along the inner membrane of Bowman's capsule. Immunohistochemistry, haematoxylin counterstain. Scale bar for all images $=50 \mu \mathrm{m}$.

length of clinical course, where animals were kept until death occurred naturally [40]. In all other studies, most animals were euthanized before advanced disease onset (Table 1). In summary, exploration and validation of such animal models is critical for the future exploration of therapeutic intervention strategies as is the development of non-human primate models for both $\mathrm{HeV}$ and $\mathrm{NiV}$ infection which has yet to be attempted in earnest.

\section{ANTIVIRAL THERAPEUTIC TARGETS}

Although there are superb examples of effective antiviral drugs that target viral replication, such as the DNA chainterminators used in the treatment of various herpes viruses and the numerous drugs that interfere with the replication of human immunodeficiency virus type 1 (HIV-1) (reviewed in [52]), for the vast majority of human viral pathogens there is a vast shortage of effective therapies. Importantly, to date, only one antiviral drug has been utilized during a henipavirus outbreak, ribavirin, which was first synthesized in 1972 [53]. It is perhaps the best known alternative drug therapy, exhibiting antiviral activity against a variety of mostly RNA viruses. Ribavirin is an accepted treatment for several viral infections including RSV, arenaviral hemorrhagic-fevers such as Lassa virus and some members of the family Bunyaviridae (reviewed in [54]). Because of its global availability and broad antiviral properties it is often employed for the treatment of viral diseases under conditions where no other options are available except supportive care. During the NiV encephalitis outbreak in Malaysia, there was evidence that ribavirin exhibited some clinical benefit [54-56] with an apparent $36 \%$ reduction in mortality with little evidence of serious side effects. Thus, ribavirin appears to be one available antiviral option; however, with fatality approaching $75 \%$ in the most recent NiV outbreaks in Bangladesh and India, a more effective repertoire of antiviral agents is needed.

$\mathrm{HeV}$ and $\mathrm{NiV}$ are transmitted oranasally, spread systemically and infected individuals succumb to disease within 7 to 10 days. Clinical and experimental data demonstrate that multiple organ systems are affected and that the lungs and brain are major sites of virus replication. Viremia has been documented in both clinical and experimental infections; however, the kinetics and duration vary. For both viruses, acute and late-onset encephalitis has been documented clinically. The initial sites and duration of henipavirus replication upon infection are largely unknown, mainly due to a lack of extensive in vivo experiments. Consequently, the optimal target and time frame for drug intervention are not known. Theoretically, therapeutics that target the mucosa should reduce viral loads in the lung. Intravenous agents should decrease viral loads and reduce systemic spread. Although targeting the CNS may prove difficult, a significant reduction in viral loads peripherally may enable the host to generate a protective immune response.

Table 2. Effective Henipavirus Vaccines

\begin{tabular}{|c|c|c|c|c|}
\hline & Immunization Schedule & Adjuvant & Challenge: Dose and Route & Immune Correlates of Survival \\
\hline \hline $\begin{array}{c}\text { Vaccinia viruses encod- } \\
\text { ing NiV F or G } \\
\text { (hamsters) }\end{array}$ & $\begin{array}{c}2 \text { subcutaneous doses } \\
\left(10^{7} \text { pfu per dose }\right) \\
1 \text { month apart }\end{array}$ & None & $\begin{array}{c}3 \text { months post immunization, } \\
1000 \text { pfu NiV intraperitoneally }\end{array}$ & $\begin{array}{c}\text { Viral load } \\
\text { Antibodies (ELISA and SNT) }\end{array}$ \\
\hline $\begin{array}{c}\text { Canarypox viruses en- } \\
\text { coding NiV F or G } \\
\text { (pigs) }\end{array}$ & $\begin{array}{c}2 \text { intramuscular doses }\left(10^{8}\right. \\
\text { pfu per dose) } \\
14 \text { days apart }\end{array}$ & None & $\begin{array}{c}29 \text { days post immunization, } \\
2.5 \times 10^{5} \text { pfu NiV intranasally }\end{array}$ & $\begin{array}{c}\text { Viral load } \\
\text { Cytokine production } \\
\text { Antibodies } \\
\text { (ELISA, IFA and SNT) }\end{array}$ \\
\hline $\begin{array}{c}\text { Recombinant HeV or } \\
\text { NiV soluble G } \\
\text { (cats) }\end{array}$ & $\begin{array}{c}3 \text { subcutaneous doses }(100 \\
\mu g \text { per dose) } \\
14 \text { days apart }\end{array}$ & $\begin{array}{c}\text { CSIRO triple } \\
\text { adjuvant }\end{array}$ & $\begin{array}{c}11 \text { weeks post immunization, } \\
500 \text { TCID } 50 \text { NiV subcutaneously }\end{array}$ & $\begin{array}{c}\text { Viral load } \\
\text { Antibodies (SNT) }\end{array}$ \\
\hline
\end{tabular}


To date, all novel henipavirus therapeutic agents that have been identified target and interfere with $\mathrm{HeV}$ and $\mathrm{NiV}$ virus entry and these candidates can be divided into two categories: those used for prevention of disease, including various vaccines, and those used for treatment post-exposure which includes antibodies, fusion inhibitors and soluble receptor molecules. The scope of this review will be limited to those agents tested using infectious $\mathrm{HeV}$ or $\mathrm{NiV}$ in vitro or in vivo.

\section{PREVENTION: VACCINE DEVELOPMENT}

The use of safe and efficacious vaccines has been crucial to prevention strategies for several important viral pathogens in humans. Presently, there are some sixteen FDA-approved vaccines routinely used to prevent infection by virulent human pathogens and the majority comprise live-attenuated virus preparations (reviewed [57]). Although new reverse genetics systems have been developed for $\mathrm{NiV}$ [58], it is unlikely that a live-attenuated vaccine will be approved for any BSL4 virus including $\mathrm{HeV}$ and $\mathrm{NiV}$. All successful human viral vaccines induce neutralizing antibodies that can cross-react with immunologically relevant strains of a virus [59]. Furthermore, neutralizing antibodies are the key vaccine-induced protective mechanisms in the case of some well known human paramyxoviruses such as mumps and $\mathrm{MeV}$ $[60,61]$. For paramyxoviruses, it is the envelope glycoproteins that elicit the majority of neutralizing antibody in an infected host [3]. Indeed, for henipaviruses, it has been demonstrated that immunization of animals with recombinant $\mathrm{NiV}$ and $\mathrm{HeV} \mathrm{F}$ or $\mathrm{G}$ glycoproteins, either as a live vaccinia virus vector or purified protein preparation can elicit potent cross-reactive virus neutralizing humoral responses in hamsters and rabbits, respectively $[62,63]$.

The first successful experimental henipavirus vaccine utilized recombinant vaccinia viruses that encoded NiV F or $\mathrm{G}$ glycoprotein. In these studies, vaccination protected against NiV challenge in golden hamsters and importantly, protection lasted five months post-challenge suggesting protection potentially from late-onset disease symptoms [62]. Although important for proof of principle, these recombinant viruses are not a viable human vaccine candidate due to the inherent risks of vaccinia virus vaccination. Poxvirus vectors have emerged as licensed veterinary vaccines as well as candidate vaccines for humans. Concerns about the safety of wild-type vaccinia virus have been addressed with the advent of attenuated poxviruses such as modified vaccinia virus Ankara (MVA), which is considered the vaccinia virus strain of choice for clinical investigation [64]. Although, recombinant MVA expressing $\mathrm{HeV} \mathrm{F}$ or $\mathrm{G}$ has been generated, neither has been tested as a vaccine candidate (Bossart, $\mathrm{K}$. and Broder, C.; unpublished data). Other poxvirus vectors shown to be attenuated in humans, such as the avipoxviruses, have also been explored as live vaccine vectors (reviewed in [65, 66]) and licensed feline, canine and equine canarypox virusbased vaccines are commercially available [67]. Recently, recombinant canarypox virus-based vaccines encoding NiV $\mathrm{F}$ or G successfully protected pigs from NiV challenge [68]. Interestingly, neutralizing antibodies and cell mediated immunity were examined and the study suggested that Gcontaining recombinant canarypox vaccines could elicit protective humoral and type 1 cell-mediated immune responses. Understanding and optimizing the immune response to henipaviruses represents a key aspect of human vaccine development. Importantly, this was the first report of recombinant canarypox virus vaccines being used in pigs and represents significant progress towards a veterinary vaccine for $\mathrm{NiV}$. Furthermore, if evaluated successfully in an independent animal model, recombinant $\mathrm{NiV} \mathrm{F-} \mathrm{and} \mathrm{G-containing} \mathrm{ca-}$ narypox vaccines could potentially be used as human $\mathrm{NiV}$ vaccine candidates.

Recombinant subunit immunogens represent a viable avenue of vaccine development for the henipaviruses. These vaccines can be quickly implemented, are quite simple, and can be administered with no risk of infection. Recently, recombinant, soluble, oligomeric versions of the G glycoprotein of both $\mathrm{HeV}$ and $\mathrm{NiV}(\mathrm{sG})$ were generated as potential subunit vaccines [63]. Recombinant, purified sG preparations have been shown to be ideal immunogens that retain a number of important functional and antigenic properties including the ability to bind virus receptor, block virus infection, and elicit a robust polyclonal neutralizing antibody response in rabbits and mice [63]. The sG glycoprotein can also capture and isolate virus-specific neutralizing human monoclonal antibodies (mAbs) from naive recombinant libraries [69]. When $\mathrm{HeV}$ and $\mathrm{NiV}$ sG were used as subunit vaccines in a cat $\mathrm{NiV}$ challenge model, all animals were protected from disease [43]. The serum neutralization titers were on the order of 1:20,000 and represented the highest titers against henipaviruses obtained to date. The high neutralizing antibody titers and the absence of $\mathrm{NiV}$ genome in all vaccinated animals following challenge suggested that the $\mathrm{sG}$ subunit vaccines elicited sterilizing immunity. Unlike previous vaccines strategies, heterotypic protection was achieved where the attachment glycoprotein from $\mathrm{HeV}$ protected against challenge with $\mathrm{NiV}$. If evaluated successfully in an additional animal model, these subunit vaccines may also represent viable human vaccine candidates. All of the potential vaccines discussed thus far are summarized in Table $\mathbf{2}$.

In order for a henipavirus vaccine to be considered for human use, not only does it need to be successful in two animal models, a natural route of infection should be used in

Table 3. Examples of Heterotypic Henipavirus Serum Titers

\begin{tabular}{|c|c|c|c|c|c|}
\hline Sera from Infected Individuals & Binding to NiV G & Binding to HeV G & Sera from sG Vaccinated Cats & SNT Titer NiV & SNT Titer HeV \\
\hline \hline HeV human & $1: 16000$ & $1: 8000$ & HeV sG cat 1 & $1: 20480$ & $1: 20480$ \\
\hline HeV horse & $1: 16000$ & $1: 32000$ & HeV sG cat 2 & $1: 20480$ & $1: 20480$ \\
\hline NiV human & $1: 32000$ & $1: 2000$ & NiV sG cat 3 & $1: 20480$ & $1: 1280$ \\
\hline NiV pig & $1: 8000$ & neg & NiV sG cat 4 & $1: 20480$ & $1: 2560$ \\
\hline
\end{tabular}

SNT = serum neutralization test. 
Table 4. Antibody Profiles of sG Vaccinated Cats

\begin{tabular}{|l|c|c|c|c|c|c|}
\hline & HeV SNT Titer & NiV SNT Titer & $\begin{array}{c}\text { SG-specific } \\
\text { Serum IgG }\end{array}$ & $\begin{array}{c}\text { SG-specific } \\
\text { Serum IgM }\end{array}$ & sG-specific Serum IgA & HeV sG-Specific Mucosal IgA \\
\hline \hline Control & $1: 32$ & $<1: 2$ & - & - & - & - \\
\hline Control & $1: 16$ & $<1: 2$ & - & - & - & - \\
\hline High dose & $1: 4096$ & $1: 512$ & + & + & + & + \\
\hline High dose & $1: 2048$ & $1: 256$ & + & + & + & + \\
\hline Medium dose & $1: 4096$ & $1: 512$ & + & + & + \\
\hline Medium dose & $1: 4096$ & $1: 256$ & + & + & - & + \\
\hline Low dose & $1: 1024$ & $1: 128$ & + & + & - & + \\
\hline Low dose & $1: 1024$ & $1: 32$ & + & + & - & + \\
\hline
\end{tabular}

SNT $=$ serum neutralization test; $\mathrm{sG}$-specific $=$ antibodies detected to both $\mathrm{HeV}$ and $\mathrm{NiV}$ sG.

protection studies, the mechanism and limits of protection should be elicited, and the highest standards should be used for reagents production to assure safety and success in human trials. Additionally, for $\mathrm{HeV}$ and $\mathrm{NiV}$, we believe it would be ideal to have one vaccine that protects against both viruses. All of the above vaccine trials offer critical data towards these goals, but further refinement of reagents and protocols are necessary. Firstly, the selection of adjuvant will be important in human use. Secondly, a correlation between vaccine dose and protection will need to be established to ensure that vaccine preparations induce protective immune responses well above sub-optimal levels. Correlations of immunity will also be critical, including antibody subclasses such as $\operatorname{IgA}$, IgG and IgM and their location (serum vs mucus membranes). Finally, it will be important to determine the role of cell-mediated type 1 immune responses in the strength and longevity of protective immunity.

To address these concerns, a new sG subunit vaccine trial has been initiated. $\mathrm{HeV} \mathrm{sG}$ was chosen as the antigen because, based on previously established G-specific cross neutralization titers $[43,70]$, it can elicit the best cross-reactive henipavirus immune response (see Table 3). Varying doses of $\mathrm{sG}$ were employed in hopes of correlating protection with vaccine dose. Additionally, small CpG DNA molecules were used as the adjuvant for several reasons. Recent studies have demonstrated that $\mathrm{CpG}$ molecules can elicit mucosal and systemic type 1 cell-mediated immune responses regardless of the route of vaccine delivery. Equally important, several CpG molecules have been approved by the FDA for use in humans and numerous others are in clinical trials. All vaccinated animals were challenged oronasally with 50,000 TCID $_{50}$ of a low passage NiV isolate. Preliminary prechallenge results are summarized in Table 4. As expected, different doses of $\mathrm{sG}$ induced varying levels of serum neutralizing antibody, and titers were significantly lower to $\mathrm{NiV}$ as compared to $\mathrm{HeV}$. Antigen-specific IgG and IgM were detected in all sera from all vaccinated animals, and sGspecific IgA was present in serum from one high dose animal. Interestingly, $\mathrm{HeV}$ sG-specific $\operatorname{IgA}$ was detected in the mucosal washes from all vaccinated animals. Post-challenge titers and protection from disease are not yet known, however, the data generated in the current vaccine trial will be valuable for future development of a human henipavirus vaccine.

\section{POST-EXPOSURE THERAPEUTICS}

\section{Antibodies}

While the neutralizing antibodies elicited by a vaccine can be highly effective, purified neutralizing antibodies administered passively to acutely infected individuals can be equally efficient. Passive antibody therapy is routinely used for prophylaxis against several important human pathogens including hepatitis B, varicella, RSV and rabies virus. With the advancement of mouse-human chimeric mAbs and the capability to 'humanize' murine mAbs, passive antibody therapy has become even more efficient. One such example includes a 'humanized' $m A b$ to RSV F protein (Syna-

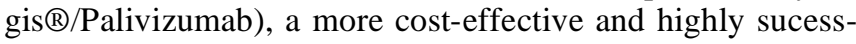
ful treatment compared to the original polyclonal product [71]. Passive therapy for NiV was first demonstrated using polyclonal hyper immune serum in hamsters [62]. Here, hamsters were administered anti-NiV F or anti-NiV G polyclonal sera prior to challenge and all animals survived subsequent NiV challenge. In more recent studies, murine mAbs directed against $\mathrm{NiV}$ F or $\mathrm{G}$ were evaluated in lethal $\mathrm{NiV}$ challenge experiments in hamsters [72]. When mAbs were administered prior to and shortly after challenge all animals were protected. However, when administered 24 hours postchallenge, only $50 \%$ of the animals survived. Together these data demonstrate that passive transfer is possible for $\mathrm{NiV}$. Importantly, to be further developed as a post-exposure therapy for human use, efficacy of this treatment needs to be increased beyond a 24 hour window, and murine mAbs may need to be converted to more humanized molecules.

A major advancement in antibody technology has been the development of the phage display platform of combinatorial antibody libraries [73] as well as domain and chain shuffling methodologies to generate antibodies with new functional properties [74]. Phage libraries encode antibodies in the form of single-chain variable region fragments (scFvs) or Fab' fragments. Human phage display platforms are the most extensively used and this technology has been complemented by innovative affinity maturation strategies to obtain high affinity reagents (reviewed [75]). These new techniques in human phage display platforms have been an enabling technology for the very rapid identification and isolation of specific mAbs, and have eliminated the time-consuming processes of immunization, hybridoma development and 
humanization techniques. Neutralizing human mAbs reactive to the $\mathrm{G}$ glycoprotein of $\mathrm{HeV}$ and $\mathrm{NiV}$ have been successfully identified, isolated, and characterized using these recombinant antibody techniques [69]. In particular, Fab' fragment m102 had significant neutralizing activities against both henipaviruses and mapped to the receptor binding domain of $\mathrm{HeV}$ and $\mathrm{NiV} \mathrm{G}[69,70]$. Subsequently, m102 was converted to a full length human IgG1 antibody, affinity maturated (m102.4) and evaluated in virus neutralization assays. The m102.4 human IgG antibody could completely neutralize both $\mathrm{HeV}$ and $\mathrm{NiV}$ at concentrations as low as 10 $\mu \mathrm{g} / \mathrm{ml}$ (Zhu, Z. and Bossart, K.; unpublished data). In light of its potency in vitro, its mechanism of neutralization and the fact that is a fully human antibody, m102.4 could provide a valuable post-exposure or post-infection therapeutic for disease caused by $\mathrm{HeV}$ or $\mathrm{NiV}$ in humans. Pharmacological assays are currently under development and will be discussed below.

\section{Fusion Inhibitory Peptides}

There have been considerable advances in mechanistic models of how several viral envelope glycoproteins function in driving the membrane fusion reaction (reviewed in [7678]). A key component of many of these fusion glycoproteins is two $\alpha$-helical domains referred to as heptad repeats (HR) that are involved in the formation of a trimer-ofhairpins structure $[79,80]$. HR-1 is located proximal to the amino (N)-terminal fusion peptide and HR-2 precedes the transmembrane domain near the carboxyl (C)-terminus [79, 81-83]. For many viral fusion glycoproteins the N-terminal HR-1 forms an interior, trimeric coiled-coil surrounded by three anti-parallel helices formed from HR-2 and the formation of this structure mediates and provides the necessary energy to drive viral-host cell membrane merger (reviewed in [84]).

Over the past decade, targeting the viral membrane fusion process for antiviral drug development has received much attention, primarily lead by work on HIV-1 (reviewed in [85]). Importantly, the HIV-1 envelope derived peptide, enfuvirtide (Fuzeon ${ }^{\mathrm{TM}}$, formerly $\mathrm{T}-20$ ), has been a clinical success $[86,87]$. Enfuvirtide is a 36-amino acid peptide corresponding to a portion of the C-terminal HR-2 domain of the gp41 subunit of the envelope glycoprotein. Peptide sequences derived from $\mathrm{F}$ glycoprotein HR domains of several paramyxoviruses, including $\mathrm{HeV}$ and $\mathrm{NiV}$ have been shown to be potent inhibitors of fusion [88-93]. Moreover, $\mathrm{HeV}$ and NiV F glycoprotein HR domains have been shown to interact with each other and form the typical 6-helix coiled-coil bundles [94].

For the henipaviruses, second generation heptad-derived peptides were synthesized with chemical modifications of either the $\mathrm{N}$ - or C-terminus of the peptide by capping and/or "pegylation", the coupling of polyethylene glycol (PEG) to proteins. Specific chemical modifications of the NiV F heptad-derived peptide were chosen, especially pegylation, to help improve plasma half-life and thus enhance therapeutic success. Pegylation is currently considered one of the most successful techniques to prolong the residence time of protein drugs in the bloodstream [95-98]. Like their predecessors, the new chemically modified heptad-derived peptides potently inhibited henipavirus infection in vitro in a dosedependent fashion [99]. The plasma half-life of these peptides was recently evaluated in cats in vivo and was found to be unusually short (Crameri, G. and Broder, C., unpublished data), especially when compared to the half-life of Enfuvirtide in humans. As pure carnivores, cats have a unique metabolism designed to convert protein into sugar and this feature may have played a role in the rapid clearance of peptides from the bloodstream. For these reasons the peptide plasma half-life is currently being reevaluated in another animal species, ferrets. Once pharmacological studies have been completed and adequate peptide plasma half-life has been demonstrated, these peptides will be administered in vivo to examine their efficacy in treatment of ongoing NiVmediated disease. It is hoped that, as was seen with enfuvirtide, the fusion inhibiting peptides might reduce viral load and or systemic spread in vivo.

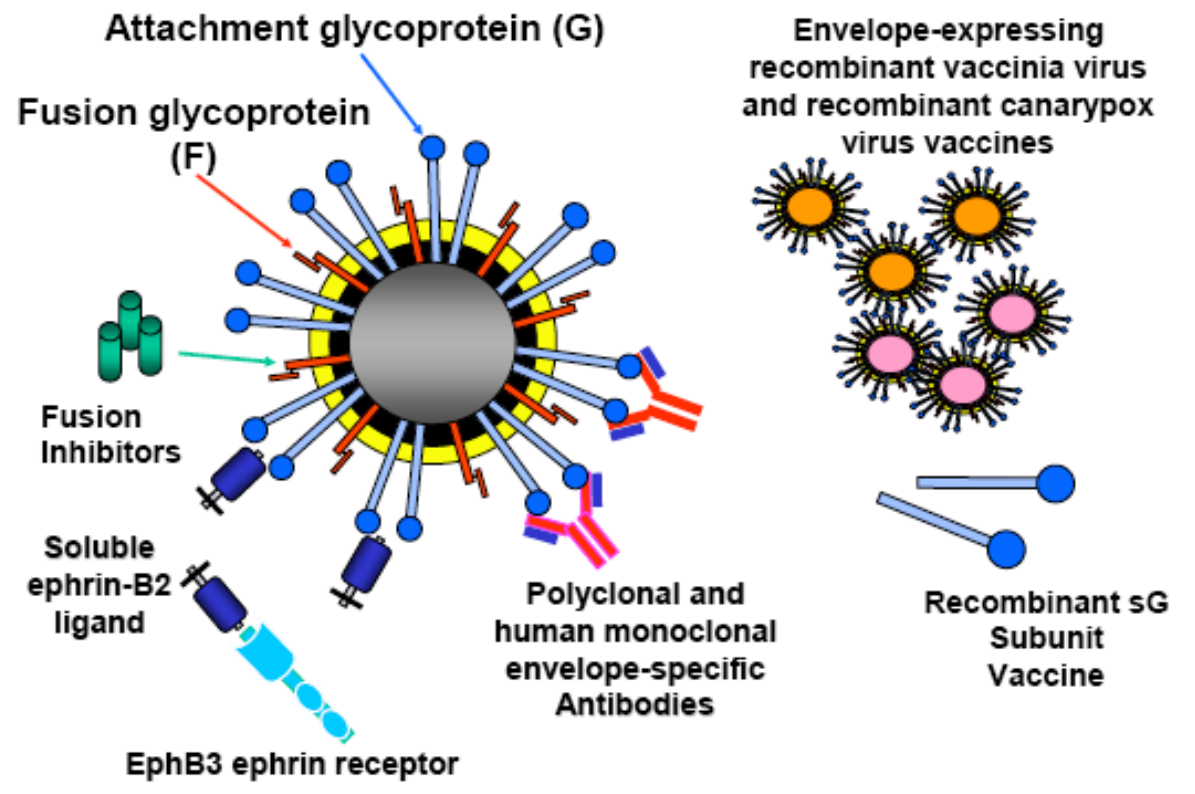

Fig. (2). Henipavirus therapeutic agents evaluated in vitro and in vivo. 


\section{Soluble Receptor Molecules}

In addition to using virus-neutralizing human mAbs or peptides as a post-exposure therapeutic modality for $\mathrm{HeV}$ and $\mathrm{NiV}$ infection, a soluble virus receptor which binds $\mathrm{G}$ and prevents attachment of the virion to the host cell may also represent a feasible therapeutic strategy. It has been demonstrated that soluble ephrin-B2 ligand can block infectious henipavirus infection in vitro [27] and more recently, it has been demonstrated that soluble ephrin-B2 ligand could block both ephrin-B2 and ephrin-B3 ligand mediated henipavirus infections in vitro (Bossart, K. and Wang, L.; unpublished data). Although only recently identified as a functional receptor for the henipaviruses, the ligand ephrin-B2 and its cellular receptor EphB4, have attracted much attention due to their roles in cancer biology [100, 101]. Currently, soluble versions of both molecules are being explored as possible therapeutic drugs for human cancer. Specifically, blocking this receptor/ligand interaction inhibits the end stage of tumor blood vessel formation and causes direct growth inhibition of certain cancers [33, 102]. Interestingly, EphB4 has no inhibitory effects on ephrin-B3 ligand mediated henipavirus infection, only EphB3 a natural receptor for ephrin-B2 and ephrin-B3 ligands, was capable of blocking all henipavirus infections in vitro (Bossart, $\mathrm{K}$. and Wang, L.; unpublished data). The potential passive therapeutic efficacy of soluble ephrin-B2 ligand or EphB3 protein in an animal model remains to be determined. However, their mechanism of action could be viewed as similar to that of a $\mathrm{G}$ glycoprotein-specific or receptor-specific antibody. A summary of all prevention and post-exposure henipavirus therapeutics is shown in Fig. (2).

\section{Pharmacology of Post-Exposure Therapeutics}

A complete understanding of plasma half-life and toxicity are required for the development of any human use therapeutic. The pharmacological properties of virus-specific human mAbs and heptad-derived peptides are currently being evaluated in vivo, and we believe that soluble ephrin-B2 ligand and EphB3 studies will commence in the not too distant future. To aid drug measurement ex vivo, new assays that exhibit extraordinary sensitivity have been developed. Differential henipavirus serology and neutralization assays using Bio-plex array systems were recently described [70]. These assays used $\mathrm{HeV}$ and $\mathrm{NiV}$ sG-coupled fluorescentlylabeled microspheres, test sera or soluble receptors and phycoerythrin-labeled detection molecules and binding results were reported as median fluorescent intensities. Although developed to detect host antibodies that interfered with receptor binding, these assays were easily adapted for measuring therapeutics that bound the attachment glycoproteins of $\mathrm{HeV}$ and NiV. The sG coupled-microspheres have been used to detect ephrin-B2 ligand and G-specific human mAbs, with approximate sensitivities of $5 \mathrm{ng} / \mathrm{ml}$ and $250 \mathrm{pg} / \mathrm{ml}$; respectively (Bossart, K. unpublished data). Clearly, these assays will prove valuable for detecting soluble ephrin-B2 ligand in sera and are already being used to measure G-specific human mAbs in sera during plasma half-life experiments. Finally, another microsphere-based assay capable of measuring Fspecific heptad-derived peptides in sera has been developed. In this assay, microspheres coated with heptad-derived peptide are detected using a peptide-specific polyclonal antibody and anti-rabbit-phycoerythrin molecules and results are re- ported as median fluorescent intensities. When test sera are added, free peptide competes for antibody binding and thus decreased fluorescent signals are detected. Similar to the other microsphere assays, this new peptide assay has an approximate sensitivity of $5 \mathrm{ng} / \mathrm{ml}$ Examples of standard curves for all assays are shown in Fig. (3). The development of such assays will enable accurate measurement of each potential therapeutic agent ex vivo and set the stage for evaluating the efficacy of each in henipavirus animal challenge models.

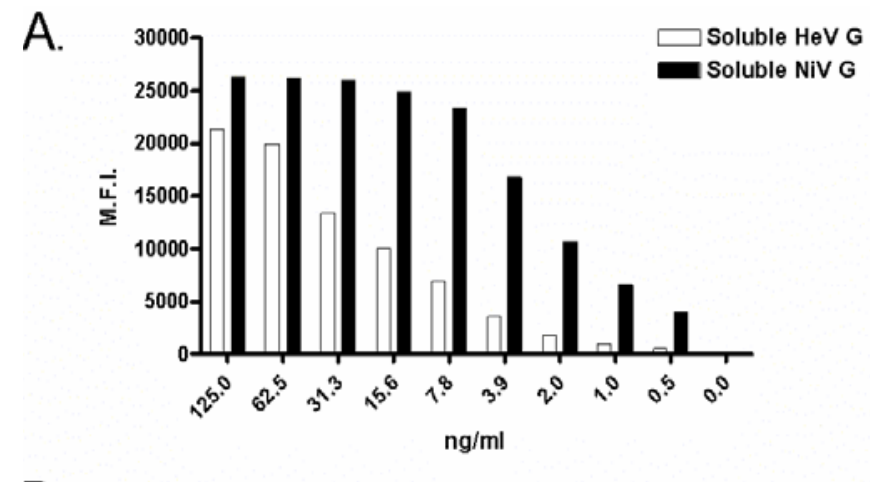

B.

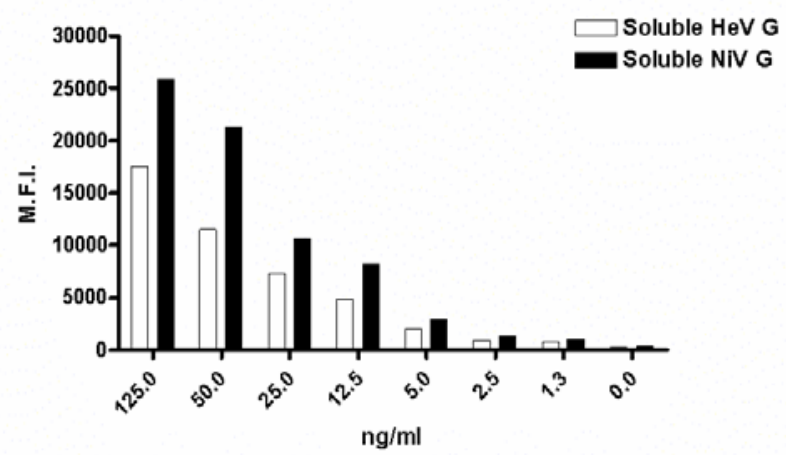

C.

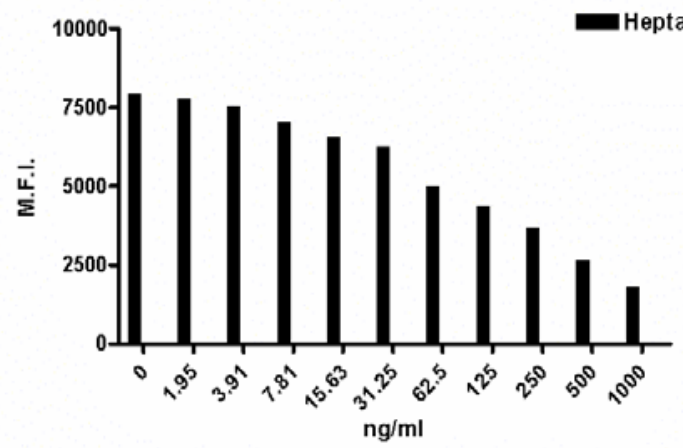

Fig. (3). Standard curves using new pharmacological assays for various post-exposure therapeutic agents. For each graph, median fluorescent intensity (M.F.I.) is shown on the $\mathrm{Y}$-axis and concentration is shown on the $\mathrm{X}$-axis. For panels $\mathbf{A}$ and $\mathbf{B}$ binding to soluble $\mathrm{HeV}$ G- and soluble NiV G-coupled microspheres are indicated by white and black bars, respectively. For panel $\mathbf{C}$ binding of antibody to peptide-coupled microspheres in the presence and absence of free peptide is indicated by black bars. A: Binding of recombinant human m102.4 IgG1 monoclonal antibody; B: Binding of recombinant soluble ephrin-B2 ligand; C: Competition by soluble heptadderived peptide.

\section{CONCLUDING REMARKS}

The increased understanding of henipavirus pathogenesis has lead to the development of suitable animal models of 
disease and potential therapeutics. The successful vaccine candidates have been trialed in one animal model but still need to be evaluated in an independent animal model. Additionally, as discussed, while providing important proof of concept data, further understanding of protection mechanisms and refinement of reagents will be critical if any vaccine candidate is to progress further. Most of the postexposure therapeutic agents have only been tested in vitro and will require in vivo half-life studies and disease prevention efficacy studies in at least two animal models. The complexities of such studies include optimizing drug delivery in vivo and site-specific targeting of post-exposure antivirals. Although many avenues of henipavirus therapeutic research have been successful, it will most likely take at least five to ten years before any therapeutic agent undergoes all necessary testing, gains FDA approval and is used routinely during an outbreak.

An understanding of the molecular biology of $\mathrm{HeV}$ and $\mathrm{NiV}$ has expanded rapidly in recent years. Although this review has been limited to those agents tested against infectious virus, numerous in vitro cell culture systems have been developed for examining various henipavirus gene-specific functions. Consequently, protein-based mechanisms, such as attachment and fusion, F cleavage, interferon interference and virus particle formation have been further elicited [103]. Importantly, these processes all represent targets for new antiviral drug development and both high throughput screening and specific inhibition assays are well underway. The construction of a NiV reverse genetics system [58], although unlikely to be used in vaccine trials, will significantly aid gene knock out studies using infectious clones and new therapeutic targets will most likely be identified. New therapeutic gene silencing techniques, such as small interfering RNA molecules, are also being developed for NiV. Characterized genes are the current targets; however, new genome regions identified using reverse genetics also represent potential sequence targets. The vast expansion of henipavirus molecular biology has underpinned new drug discovery; however, virus neutralization assays, drug characterization in vivo and efficacy studies still represent the most challenging phases of drug development for $\mathrm{HeV}$ and $\mathrm{NiV}$, especially under BSL-4 restrictions.

\section{ACKNOWLEDGEMENTS}

The authors wish to specifically thank Gary Crameri for providing unpublished data generated using peptide-based microsphere assays for inclusion in this review. The authors also wish to thank Michael Johnson and Wojtek Michalski for critical review of this review prior to its submission. This study was supported in part by a Geelong Research Award to KNB (AAHL DR59F), in part by a grant to KNB from the Jack Brockhoff Foundation (AAHL KW96B), and the ABCRC grant 1.013RE.

\section{REFERENCES}

[1] Halpin K, Young PL, Field HE, Mackenzie JS. Isolation of Hendra virus from pteropid bats: a natural reservoir of Hendra virus. J Gen Virol 2000; 81: 1927-32.

[2] Chua KB, Lek Koh C, Hooi PS, et al. Isolation of Nipah virus from Malaysian Island flying-foxes. Microbes Infect 2002; 4: 145-51.

[3] Lamb RA, Parks GD. Paramyxoviridae: The viruses and their replication. In: Knipe DM, Howley PM, Eds. Fields Virology; 5 ed. Philadelphia, Lippincott, Williams \& Wilkins 2007; 1449-96.
[4] Wang L, Harcourt BH, Yu M, et al. Molecular biology of Hendra and Nipah viruses. Microbes Infect 2001; 3: 279-87.

[5] Eaton BT, Broder CC, Middleton D, Wang LF. Hendra and Nipah viruses: different and dangerous. Nat Rev Microbiol 2006; 4: 2335 .

[6] Westbury HA. Hendra virus disease in horses. Rev Sci Tech 2000; 19: 151-9.

[7] Hanna JN, McBride WJ, Brookes DL, et al. Hendra virus infection in a veterinarian. Med J Aust 2006; 185: 562-4.

[8] Anonymous. Hendra virus, equine - Australia (NSW): susp.: International Society for Infectious Diseases 2006; Report No.: 20061109.3222 .

[9] Chua KB. Nipah virus outbreak in Malaysia. J Clin Virol 2003; 26: 265-75.

[10] Tan CT, Wong KT. Nipah encephalitis outbreak in Malaysia. Ann Acad Med Singapore 2003; 32: 112-7.

[11] Hsu VP, Hossain MJ, Parashar UD, et al. Nipah Virus Encephalitis Reemergence, Bangladesh. Emerg Infect Dis 2004; 10: 2082-7.

[12] Harit AK, Ichhpujani RL, Gupta S, et al. Nipah/Hendra virus outbreak in Siliguri, West Bengal, India in 2001. Indian J Med Res 2006; 123: 553-60.

[13] Anonymous. Emerging Infections update: November 2004 to January 2005. Communicable Disease Report Weekly (CDR Weekly) $2005 ; 15(6)$.

[14] Anonymous. Nipah encephalitis outbreak over wide area of western Bangladesh, 2004. Health and Science Bulletin (ICDDR,B) 2004; 2: 7-11.

[15] Anonymous. Nipah virus, fatal - India (West Bengal) (02) International Society for Infectious Diseases 2007; Report No.: 20070511 1514.

[16] Gurley E, Montgomery JM, Hossain MJ, Bell M, Azad AK, Islam MR. Person-to-person transmission of Nipah virus in a Bangladeshi community. Emerg Infect Dis 2007; Epub ahead of print.

[17] Luby SP, Rahman M, Hossain MJ, et al. Foodborne transmission of Nipah virus, Bangladesh. Emerg Infect Dis 2006; 12: 1888-94.

[18] Hooper P, Zaki S, Daniels P, Middleton D. Comparative pathology of the diseases caused by Hendra and Nipah viruses. Microbes Infect $2001 ; 3: 315-22$.

[19] Lam SK, Chua KB. Nipah virus encephalitis outbreak in Malaysia. Clin Infect Dis 2002; 34: S48-51.

[20] Wong KT, Shieh WJ, Kumar S, et al. Nipah virus infection: pathology and pathogenesis of an emerging paramyxoviral zoonosis. Am J Pathol 2002; 161: 2153-67.

[21] Dorig RE, Marcil A, Chopra A, Richardson CD. The human CD46 molecule is a receptor for measles virus (Edmonston strain). Cell 1993; 75: 295-305.

[22] Naniche D, Varior-Krishnan G, Cervoni F, et al. Human membrane cofactor protein (CD46) acts as a cellular receptor for measles virus. J Virol 1993; 67: 6025-32.

[23] Nussbaum O, Broder CC, Moss B, Stern LB, Rozenblatt S, Berger EA. Functional and structural interactions between measles virus hemagglutinin and CD46. J Virol 1995; 69: 3341-9.

[24] Tatsuo H, Ono N, Tanaka K, Yanagi Y. SLAM (CDw150) is a cellular receptor for measles virus. Nature 2000; 406: 893-7.

[25] Tatsuo H, Ono N, Yanagi Y. Morbilliviruses use signaling lymphocyte activation molecules (CD150) as cellular receptors. J Virol 2001; 75: 5842-50.

[26] Baron MD. Wild-type Rinderpest virus uses SLAM (CD150) as its receptor. J Gen Virol 2005; 86: 1753-7.

[27] Bonaparte MI, Dimitrov AS, Bossart KN, et al. Ephrin-B2 ligand is a functional receptor for Hendra virus and Nipah virus. Proc Natl Acad Sci USA 2005; 102: 10652-7.

[28] Negrete OA, Levroney EL, Aguilar HC, et al. EphrinB2 is the entry receptor for Nipah virus, an emergent deadly paramyxovirus. Nature 2005; 436: 401-5.

[29] Negrete OA, Wolf MC, Aguilar HC, et al. Two key sesidues in EphrinB3 are critical for its use as an alternative receptor for Nipah virus. PLoS Pathog 2006; 2(2): e7.

[30] Poliakov A, Cotrina M, Wilkinson DG. Diverse roles of Eph receptors and ephrins in the regulation of cell migration and tissue assembly. Dev Cell 2004; 7: 465-80.

[31] Drescher U. Eph family functions from an evolutionary perspective. Curr Opin Genet Dev 2002; 12: 397-402.

[32] Palmer A, Klein R. Multiple roles of ephrins in morphogenesis, neuronal networking, and brain function. Genes Dev 2003; 17: 1429-50. 
[33] Wang HU, Chen ZF, Anderson DJ. Molecular distinction and angiogenic interaction between embryonic arteries and veins revealed by ephrin-B2 and its receptor Eph-B4. Cell 1998; 93: 741-53.

[34] Adams RH, Wilkinson GA, Weiss C, et al. Roles of ephrinB ligands and EphB receptors in cardiovascular development: demarcation of arterial/venous domains, vascular morphogenesis, and sprouting angiogenesis. Genes Dev 1999; 13: 295-306.

[35] Bossart KN, Broder CC. Paramyxovirus entry. In: Pohlmann S, Simmons G, Eds. Viral Entry into Host Cells. Austin, Landes Bioscience / Eurekah 2007; in press.

[36] Hooper PT, Westbury HA, Russell GM. The lesions of experimental equine morbillivirus disease in cats and guinea pigs. Vet Pathol 1997; 34: 323-9.

[37] Williamson MM, Hooper PT, Selleck PW, Westbury HA, Slocombe RF. Experimental hendra virus infectionin pregnant guinea-pigs and fruit Bats (Pteropus poliocephalus). J Comp Pathol 2000; 122: 201-7.

[38] Williamson MM, Hooper PT, Selleck PW, Westbury HA, Slocombe RF. A guinea-pig model of Hendra virus encephalitis. J Comp Pathol 2001; 124: 273-9.

[39] Middleton DJ, Morrissy CJ, van der Heide BM, et al. Experimental Nipah Virus Infection in Pteropid Bats (Pteropus poliocephalus). J Comp Pathol 2007; 136: 266-72.

[40] Wong KT, Grosjean I, Brisson C, et al. A golden hamster model for human acute Nipah virus infection. Am J Pathol 2003; 163: 2127-37.

[41] Westbury HA, Hooper PT, Brouwer SL, Selleck PW. Susceptibility of cats to equine morbillivirus. Aust Vet J 1996; 74: 132-4.

[42] Middleton DJ, Westbury HA, Morrissy CJ, et al. Experimental Nipah virus infection in pigs and cats. J Comp Pathol 2002; 126: 124-36.

[43] Mungall BA, Middleton D, Crameri G, et al. Feline model of acute Nipah virus infection and protection with a soluble glycoproteinbased subunit vaccine. J Virol 2006; 80: 12293-302.

[44] Hooper PT, Ketterer PJ, Hyatt AD, Russell GM. Lesions of experimental equine morbillivirus pneumonia in horses. Vet Pathol 1997; 34: 312-22.

[45] Yob JM, Field H, Rashdi AM, et al. Nipah virus infection in bats (order Chiroptera) in peninsular Malaysia. Emerg Infect Dis 2001; 7: 439-41.

[46] Westbury HA, Hooper PT, Selleck PW, Murray PK. Equine morbillivirus pneumonia: susceptibility of laboratory animals to the virus. Aust Vet J 1995; 72: 278-9.

[47] Zitzow LA, Rowe T, Morken T, Shieh WJ, Zaki S, Katz JM. Pathogenesis of avian influenza A (H5N1) viruses in ferrets. J Virol 2002; 76: 4420-9.

[48] Martina BE, Haagmans BL, Kuiken T, et al. Virology: SARS virus infection of cats and ferrets. Nature 2003; 425: 915.

[49] Svitek N, von Messling V. Early cytokine mRNA expression profiles predict Morbillivirus disease outcome in ferrets. Virology 2007; 362: 404-10.

[50] Ball RS. Issues to consider for preparing ferrets as research subjects in the laboratory. Ilar J 2006; 47: 348-57.

[51] Gad S. Pigs and ferrets as models in toxicology and biological safety assessment. Int J Toxicol 2000; 19: 149-168.

[52] Coen DM, Richman DD. Antiviral agents. In: Knipe DM, Howley PM, Eds. Fields Virology; 5 ed. Philadelphia, Lippincott, Williams \& Wilkins 2007; 447-485.

[53] Sidwell RW, Huffman JH, Khare GP, Allen LB, Witkowski JT, Robins RK. Broad-spectrum antiviral activity of Virazole: 1-betaD-ribofuranosyl-1,2,4-triazole-3-carboxamide. Science 1972; 177: 705-6.

[54] Snell NJ. Ribavirin--current status of a broad spectrum antiviral agent. Expert Opin Pharmacother 2001; 2: 1317-24.

[55] Chong HT, Kamarulzaman A, Tan CT, et al. Treatment of acute Nipah encephalitis with ribavirin. Ann Neurol 2001; 49: 810-3.

[56] Snell NJ. Ribavirin therapy for nipah virus infection. J Virol 2004; 78: 10211 .

[57] Graham BS, Crowe JE. Immunization Against Viral Diseases. In: Knipe DM, Howley PM, Eds. Fields Virology; 5 ed. Philadelphia, Lippincott, Williams \& Wilkins 2007; 487-538.

[58] Yoneda M, Guillaume V, Ikeda F, et al. Establishment of a Nipah virus rescue system. Proc Natl Acad Sci USA 2006; 103: 16508-13.

[59] Quinnan GV. Immunization against viral diseases. In: Galasso G, Whitley R, Merigan TC, Eds. Antiviral Agents and Human Viral Disease; New York, Raven Press; 1997; 791-834.
[60] Pantaleo G, Koup RA. Correlates of immune protection in HIV-1 infection: what we know, what we don't know, what we should know. Nat Med 2004; 10: 806-10.

[61] Griffin DE. Immune responses during measles virus infection. Curr Top Microbiol Immunol 1995; 191: 117-34.

[62] Guillaume V, Contamin H, Loth $\mathrm{P}$, et al. Nipah virus: vaccination and passive protection studies in a hamster model. J Virol 2004; 78 : 834-40.

[63] Bossart KN, Crameri G, Dimitrov AS, et al. Receptor binding, fusion inhibition and induction of cross-reactive neutralizing antibodies by a soluble G glycoprotein of Hendra virus. J Virol 2005; 79: 6690-702.

[64] Sutter G, Staib C. Vaccinia vectors as candidate vaccines: the development of modified vaccinia virus Ankara for antigen delivery. Curr Drug Targets Infect Disord 2003: 263-71.

[65] Franchini G, Gurunathan S, Baglyos L, Plotkin S, Tartaglia J. Poxvirus-based vaccine candidates for HIV: two decades of experience with special emphasis on canarypox vectors. Expert Rev Vaccines 2004; 3: S75-88.

[66] Broder CC, Earl PL. Recombinant vaccinia viruses. Design, generation, and isolation. Mol Biotechnol. 1999; 13: 223-45.

[67] Poulet H, Brunet S, Boularand C, et al. Efficacy of a canarypox virus-vectored vaccine against feline leukaemia. Vet Rec. 2003; 153: $141-5$.

[68] Weingartl HM, Berhane Y, Caswell JL, et al. Recombinant nipah virus vaccines protect pigs against challenge. J Virol 2006;80: 7929-38.

[69] Zhu Z, Dimitrov AS, Bossart KN, et al. Potent neutralization of Hendra and Nipah viruses by human monoclonal antibodies. J Virol 2006; 80: 891-9.

[70] Bossart KN, McEachern JA, Hickey AC, et al. Neutralization assays for differential henipavirus serology using Bio-Plex Protein Array Systems. J Virol Methods 2007; 142: 29-40.

[71] Zeitlin L, Cone RA, Moench TR, Whaley KJ. Preventing infectious disease with passive immunization. Microbes Infect 2000; 2: 701-8.

[72] Guillaume V, Contamin H, Loth P, et al. Antibody prophylaxis and therapy against Nipah virus infection in hamsters. J Virol 2006; 80: 1972-8.

[73] Rader C, Barbas CF, 3rd. Phage display of combinatorial antibody libraries. Curr Opin Biotechnol 1997; 8: 503-8.

[74] Hayden MS, Gilliland LK, Ledbetter JA. Antibody engineering. Curr Opin Immunol 1997; 9: 201-12.

[75] Hudson PJ, Souriau C. Recombinant antibodies for cancer diagnosis and therapy. Expert Opin Biol Ther 2001; 1: 845-55.

[76] Weissenhorn W, Dessen A, Calder LJ, Harrison SC, Skehel JJ, Wiley DC. Structural basis for membrane fusion by enveloped viruses. Mol Membr Biol 1999; 16: 3-9.

[77] Chan DC, Kim PS. HIV entry and its inhibition. Cell 1998; 93: 681-4.

[78] Skehel JJ, Wiley DC. Coiled coils in both intracellular vesicle and viral membrane fusion. Cell 1998; 95: 871-4.

[79] Singh M, Berger B, Kim PS. LearnCoil-VMF: computational evidence for coiled-coil-like motifs in many viral membrane-fusion proteins. J Mol Biol 1999; 290: 1031-41.

[80] Hughson FM. Enveloped viruses: a common mode of membrane fusion? Curr Biol 1997; 7: R565-9.

[81] $\mathrm{Xu} \mathrm{Y,} \mathrm{Gao} \mathrm{S,} \mathrm{Cole} \mathrm{DK,} \mathrm{et} \mathrm{al.} \mathrm{Basis} \mathrm{for} \mathrm{fusion} \mathrm{inhibition} \mathrm{by} \mathrm{pepti-}$ des: analysis of the heptad repeat regions of the fusion proteins from Nipah and Hendra viruses, newly emergent zoonotic paramyxoviruses. Biochem Biophys Res Commun 2004; 315: 664-70.

[82] Bossart KN, Wang LF, Eaton BT, Broder CC. Functional expression and membrane fusion tropism of the envelope glycoproteins of Hendra virus. Virology 2001; 290: 121-35.

[83] Chambers P, Pringle CR, Easton AJ. Heptad repeat sequences are located adjacent to hydrophobic regions in several types of virus fusion glycoproteins. J Gen Virol 1990; 71: 3075-80.

[84] Earp LJ, Delos SE, Park HE, White JM. The many mechanisms of viral membrane fusion proteins. Curr Top Microbiol Immunol 2005; 285: 25-66.

[85] Weiss CD. HIV-1 gp41: mediator of fusion and target for inhibition. AIDS Rev 2003; 5: 214-21.

[86] Kilby JM, Hopkins S, Venetta TM, et al. Potent suppression of HIV-1 replication in humans by T-20, a peptide inhibitor of gp41mediated virus entry. Nat Med 1998; 4: 1302-7.

[87] Kilby JM, Lalezari JP, Eron JJ, et al. The safety, plasma pharmacokinetics, and antiviral activity of subcutaneous enfuvirtide (T- 
20), a peptide inhibitor of gp41-mediated virus fusion, in HIVinfected adults. AIDS Res Hum Retroviruses 2002; 18: 685-93.

[88] Lambert DM, Barney S, Lambert AL, et al. Peptides from conserved regions of paramyxovirus fusion (F) proteins are potent inhibitors of viral fusion. Proc Natl Acad Sci USA 1996; 93: 2186-91.

[89] Joshi SB, Dutch RE, Lamb RA. A core trimer of the paramyxovirus fusion protein: parallels to influenza virus hemagglutinin and HIV1 gp41. Virology 1998; 248: 20-34.

[90] Wild TF, Buckland R. Inhibition of measles virus infection and fusion with peptides corresponding to the leucine zipper region of the fusion protein. J Gen Virol 1997; 78: 107-11.

[91] Young JK, Li D, Abramowitz MC, Morrison TG. Interaction of peptides with sequences from the Newcastle disease virus fusion protein heptad repeat regions. J Virol 1999; 73: 5945-56.

[92] Rapaport D, Ovadia M, Shai Y. A synthetic peptide corresponding to a conserved heptad repeat domain is a potent inhibitor of Sendai virus-cell fusion: an emerging similarity with functional domains of other viruses. EMBO J 1995; 14: 5524-31.

[93] Bossart KN, Wang LF, Flora MN, et al. Membrane fusion tropism and heterotypic functional activities of the Nipah virus and Hendra virus envelope glycoproteins. J Virol 2002; 76: 11186-98.

[94] Xu Y, Lou Z, Liu Y, et al. Crystallization and preliminary crystallographic analysis of the fusion core from two new zoonotic paramyxoviruses, Nipah virus and Hendra virus. Acta Crystallogr D Biol Crystallogr 2004; 60: 1161-4.

[95] Harris JM, Martin NE, Modi M. Pegylation: a novel process for modifying pharmacokinetics. Clin Pharmacokinet 2001; 40: 53951.
[96] Delgado C, Pedley RB, Herraez A, et al. Enhanced tumour specificity of an anti-carcinoembrionic antigen Fab' fragment by poly(ethylene glycol) (PEG) modification. Br J Cancer 1996; 73: 17582.

[97] Delgado C, Malik F, Selisko B, Fisher D, Francis GE. Quantitative analysis of polyethylene glycol (PEG) in PEG-modified proteins/cytokines by aqueous two-phase systems. J Biochem Biophys Methods 1994; 29: 237-50.

[98] Caliceti P, Veronese FM. Pharmacokinetic and biodistribution properties of poly(ethylene glycol)-protein conjugates. Adv Drug Deliv Rev 2003; 55: 1261-77.

[99] Bossart KN, Mungall BA, Crameri G, Wang LF, Eaton BT, Broder CC. Inhibition of Henipavirus fusion and infection by heptadderived peptides of the Nipah virus fusion glycoprotein. Virol $\mathbf{J}$ 2005; 2: 57.

[100] Masood R, Xia G, Smith DL, et al. Ephrin B2 expression in Kaposi sarcoma is induced by human herpesvirus type 8: phenotype switch from venous to arterial endothelium. Blood 2005; 105: 1310-8.

[101] Martiny-Baron G, Korff T, Schaffner F, et al. Inhibition of tumor growth and angiogenesis by soluble EphB4. Neoplasia 2004; 6: 248-57.

[102] Surawska H, Ma PC, Salgia R. The role of ephrins and Eph receptors in cancer. Cytokine Growth Factor Rev 2004; 15: 419-33.

[103] Eaton BT, Mackenzie JS, Wang LF. Henipaviruses: In: Knipe DM, Howley PM, Eds. Fields Virology; 5 ed. Philadelphia, Lippincott, Williams \& Wilkins 2007; 1587-1600. 